\title{
Beberapa Sumbangan Pemikiran Bagi Konsep "Rencana Pelestarian
}

Situs Kedulan"

\section{Sugeng Riyanto}

Keywords: conservation, planning, restoration, management, protection, utilization, heritage

\section{How to Cite:}

Riyanto, S. (2005). Beberapa Sumbangan Pemikiran Bagi Konsep "Rencana Pelestarian Situs Kedulan". Berkala Arkeologi, 25(1), 119-130. https://doi.org/10.30883/jba.v25i1.916

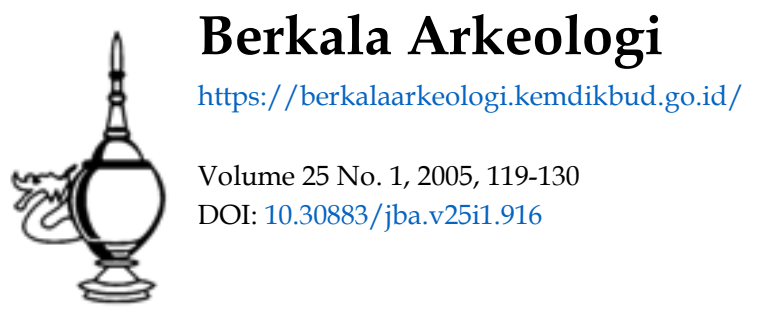

\section{c) 7 () (2)}

This work is licensed under a Creative Commons Attribution-NonCommercial-ShareAlike 4.0 International License. 


\title{
BEBERAPA SUMBANGAN PEMIKIRAN BAGI KONSEP "RENCANA PELESTARIAN SITUS KEDULAN"
}

\author{
Oleh : Sugeng Riyanto
}

\section{PENDAhuluan}

Candi Kedulan yang terletak di

Dusun Kedulan, Kelurahan

Tirtomartani,

Kecamatan

Kalasan, Sleman, DIY, merupakan salah situs yang relatif baru karena ditemukan pada tahun 1993. Namun demikian, berbagai kegiatan arkeologis, baik penelitian maupun upaya pelestarian, khususnya pemugaran, telah mencapai tahap rekonstruksi baik di atas kertas

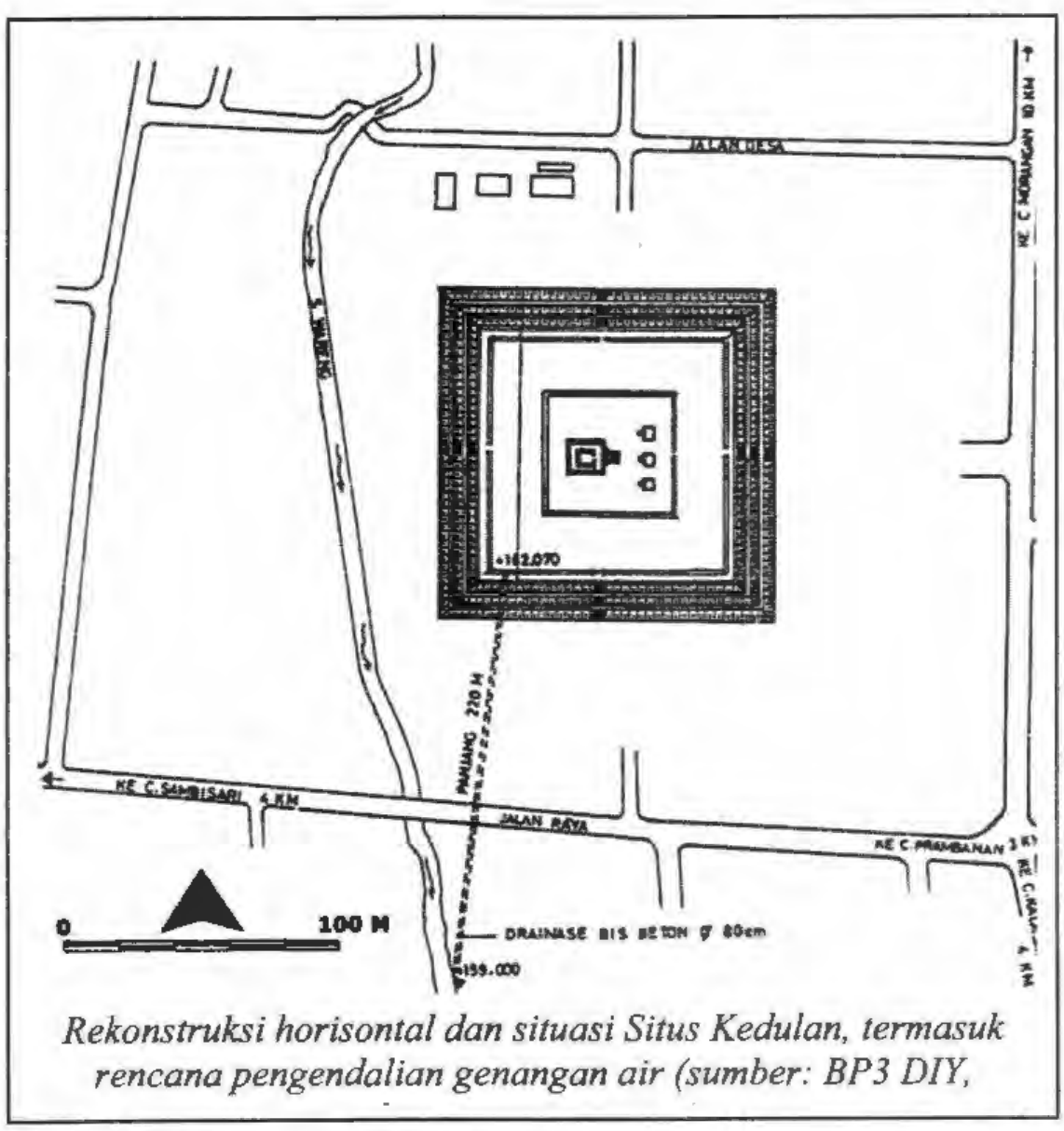
maupun susunan percobaan pada bangunan induk.

Berdasarkan hal itu dan ditambah dengan beberapa petimbangan yang lain seperti pertimbangan yuridis, kewenangan, tanggung jawab, serta teknis, maka pada tahun 2000 Suaka Peninggalan Sejarah dan Purbakala (sekarang BP3) menyusun konsep "Rencana Pelestarian Situs Kedulan". Langkah ini sangat penting baik untuk kepentingan ideologik, akademik, maupun ekonomik, sehingga perlu didukung oleh banyak pihak. Beberapa faktor pendukung konsep ini yang paling penting antara lain: 1) lebih dari $85 \%$ bahan bangunan candi (utama) berhasil ditemukan, 2) kegiatan konservasi (khususnya usaha pemugaran) telah mencapai tahap rekonstruksi baik di atas kertas maupun susunan percobaan, 3) Dari tahap 
ini, diperoleh dasar untuk menganalogikan dengan Candi Sambisari, 4) secara langsung, kegiatan ini didukung oleh Pemda Kabupaten Sleman.

Dengan demikian, konsep yang telah tersusun memang memiliki banyak arti penting, sehingga secara keseluruhan perlu mencerminkan berbagai kepentingan, dan tidak saja berorientasi kepada kepentingan arkeolog. Hal inilah yang melatarbelakangi munculnya gagasan untuk memberikan sumbangan pemikiran bagi konsep "Rencana Pelestarian Situs Kedulan".

\section{KERANGKA KONSERVASI}

Dalam batas tertentu, antara konservasi, pelestarian, dan pemugaran memiliki kaitan yang sangat erat, baik dalam hal pengertian maupun prinsip operasionalnya. Berikut ini diuraikan dua hal yang menyangkut topik tersebut, dan secara khusus meliputi kerangka pengertian tentang konservasi dan kerangka prinsip pemugaran.

\section{2.a Kerangka Pengertian}

Paling tidak, kerangka konservasi dapat dibedakan berdasarkan dua fase, yaitu "fase lama" dan "fase baru". Fase lama menempatkan konservasi sebagai bagian atau sama dengan kegiatan pemugaran, atau pelestarian, atau rekonstruksi, seperti beberapa pendapat berikut ini:

- Parmono Atmadi (1981:45): mengutip pendapat A. Dobby (1978) memberikan urutan kegiatan pemugaran dengan menempatkan konservasi sebagai kegiatan hilir, yaitu: 1) preservation, 2) repair, 3) restoration, 4) reconstruction, 5) enhancement, 6) demolition, dan 7) conservation.

- Basoeki (1982:623): rekonstruksi atau pemugaran berarti memulihkan kembali bangunan-bangunan purbakala yang rusak atau runtuh pada bentuk dan ukuran aslinya. Pelaksanaannya hanya khusus pada bangunan-bangunan yang bentuknya simetris.

- Soekmono (1994:280;282): konservasi oleh Soekmono cenderung didudukkan pada teknik bangun dan kimia (architectural conservation dan chemical conservation) dan cenderung menggunakan istilah pemugaran untuk pelestarian obyek arkeologi, yaitu perbaikan dan pemulihan kembali atas dasar dan dengan menggunakan bahan-bahan aslinya. Artinya, istilah konservasi masih "asing" untuk digunakan sebagai kerangka segala kegiatan yang berkaitan dengan pelestarian tinggalan arkeologi.

- Bambang PH dan Tri Hartono (1997:195) : pemugaran meliputi:

restorasi, rekonstruksi, rehabilitasi, konsolidasi, dan konservasi. 
Sementara itu, pengertian konservasi mutakhir (fase baru) menempatkan konservasi sebagai payung untuk segala kegiatan yang berkaitan dengan pelestarian. Khusus untuk obyek arkeologi, konservasi diartikan sebagai "mengelola dan memelihara agar dapat dimanfaatkan lebih lama dengan tetap memelihara makna kulturalnya" (Subroto, 2003: 4).

Pada dasamya, pengertian ini mengadopsi istilah konservasi yang digunakan pada sektor lain, khususnya konservasi alam. Di banyak negara, konservasi sekarang bukan hanya menjadi kebutuhan, akan tetapi sudah dimasukkan dalam kerangka legalitas. Konservasi yang semula diterapkan pada sumberdaya alam dan kehidupan liar, belakangan juga diterapkan pada tinggalan arkeologi: that policy will apply to natural resources and wildlife, but it will also apply to archaeological remains (Renfrew dan Paul Bahn, 1996: 521). Dalam hal ini ada dua tahapan mendasar dalam konservasi, yaitu:

l) gathering of information, so that relevant sites and areas may be recognized and properly recorded

2) the conservation of those sites and areas that can be effectively protected Sementara itu, dalam pengantarnya, Schiffer menempatkan konservasi bersamasama dengan contract archaeology, cultural resource management, emergency, dan salvage archaeology untuk menunjuk arkeologi secara filosofis dan kebutuhan kegiatan yang berkaitan dengan perubahan muka bumi akibat kegiatan pembangunan. Secara khusus dijelaskan bahwa conservation archaeology bukanlah kegiatan yang sekedar untuk menyelamatkan situs, tetapi lebih ditekankan pada pemanfaatan tinggalan budaya untuk kepentingan ilmiah dan masa lalu secara luas (1977: xix).

Menurut I. G. N. Anom, pengertian konservasi dapat diartikan dalam dua lingkup, yaitu lingkup luas dan lingkup khusus. Secara luas, pengertian konservasi adalah segala kegiatan pelestarian yang antara lain meliputi pemugaran, perlindungan, pemeliharaan, dan pemanfaatan, sedangkan dalam pengertian khusus, konservasi diartikan sebagai kegiatan pemeliharaan BCB baik pemeliharaan secara kimia maupun manual.

Berkaitan dengan pengertian dalam lingkup luas, Ph. Soebroto (1997: 10; 2003: 9) menyatakan, konservasi dapat dikatakan sebagai payung yang meliputi beberapa kegiatan yaitu:

- Maintanance

: pemeliharaan berkesinambungan

- Preservation

: pengawetan tanpa perubahan

- Restoration : mengembalikan obyek pada aslinya tanpa bahan baru

- Reconstruction : mengembalikan obyek pada bentuk mendekati aslinya 
- Adaptation : memodifikasi obyek sesuai dengan penggunaannya

\section{2.b. Kerangka Prinsip Pemugaran}

Pada awal abad ke-20 pemugaran memang sempat dianggap sebagai suatu hal yang "tabu". N.J. Krom terutama yang menolak dengan keras kegiatan rekonstruksi fisik, karena dianggap sebagai pemalsuan bukti sejarah dan tidak ada manfaatnya bagi ilmu pengetahuan. Menurutnya, secara ilmiah rekonstruksi hanya boleh dilaksanakan di atas kertas karena rekonstruksi secara fisik memungkinkan terjadinya kesalahan-kesalahan (Soediman, 1982: 635). Namun pada masa kemudian, pemugaran justru menjadi hal yang "wajib", seperti pada era F.D.K. Bosch yang menggantikan Krom pada tahun 1916. Bosch mempunyai pandangan yang berbeda dengan Krom dan justru sangat gigih untuk memperjuangkan rekonstruksi fisik.

Perbedaan prinsip kedua tokoh ini terletak pada orientasi. Krom berorientasi kepada ilmiah murni, sedangkan Bosch cenderung menempatkan bangunan candi sebagai bagian dari kepentingan masyarakat umum. Oleh karena itu, berdasarkan pengalamannya di kompleks Candi Panataran, dia bahkan akhirnya berpedapat bahwa dalam keadaan tertentu, pembinaan kembali adalah keharusan (Soediman, 1982: 636-7).

Berdasarkan orientasi dan pandangan Bosch bahwa pemugaran atau konservasi bangunan candi tidak boleh menjadi monopoli kalangan akademis tetapi juga meliputi kalangan umum, maka segala informasi berkenaan dengan makna kultural (Subroto, 2003: 4), sebuah candi semestinya tidak boleh terdistorsi yang diakibatkan oleh kegiatan pemugaran itu sendiri. Dengan demikian menjadi penting artinya untuk menginformasikan segala sesuatu yang berkaitan dengan riwayat pemugaran, selengkap mungkin agar bisa dimanfaatkan bukan hanya untuk kepentingan pemugaran, akan tetapi kepentingan lainnya, seperti akademik (ilmu pengetahuan), ideologik (pendidikan), dan ekonomik (kepariwisataan).

Dalam pemugaran memang dikenal tiga prinsip yang telah diakui secara luas, yaitu (Price, 1990; Tanudirjo, 1998: 16):

1) azas keterbalikan (reversibility): bentuk asli harus dapat dikembalikan, atau terbuka pada kemungkinan cara pemugaran yang lebih baik di kemudian hari

2) intervensi minimal: mengupayakan perubahan sekecil mungkin terhadap nilai estetis dan kandungan informasinya

3) kesesuaian bahan: bahan asli dan tambahan harus sama dan kelihatan menyatu dengan baik. 

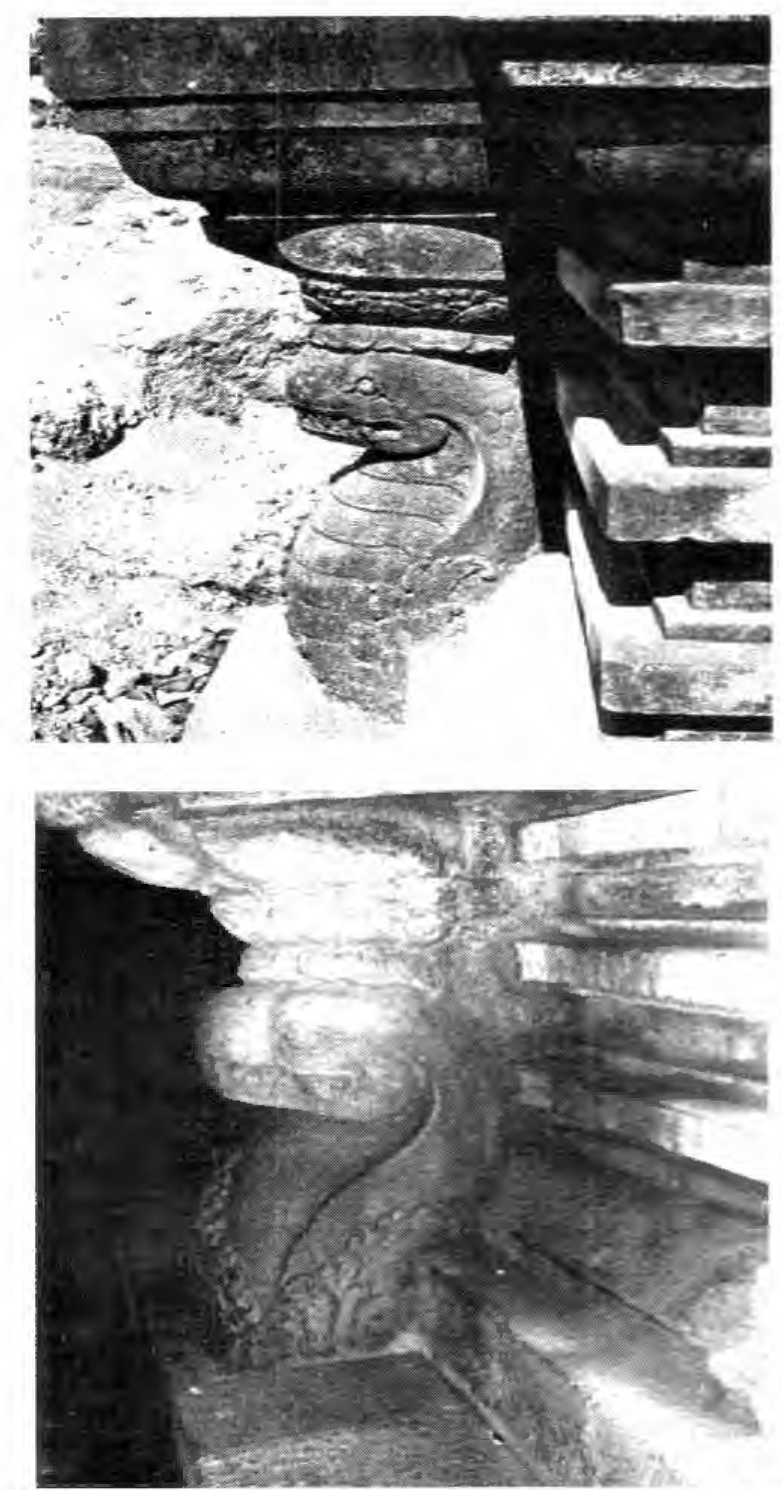

Yoni dengan profil naga, padma, dan kura-kura di Candi Kedulan (atas) dan Candi Sambisari

(bawah) sebagai salah satu dasar analogi dalam pemugaran

- tubuh bangunan induk yang berbentuk bujur sangkar berukuran $5,80 \times 5,80$ dengan tinggi 2,60 meter.

- berdasarkan beberapa indikasi, sementara dapat dianalogikan dengan Candi Sambisari untuk sebagian besar bagiannya, kecuali arah hadapnya.

- lapisan tanah yang menimbun bangunan sekitar 7 meter ini berasal dari endapan lahar Gunung Merapi yang terbawa oleh arus banjir.

- Faktor utama penyebab keruntuhan candi adalah banjir lahar dingin yang mampu menghanyutkan lumpur, pasir, kerikil, krakal, dan batu-batu kali berukuran besar yang menerjang sekaligus menimbun bangunan candi

- Aktivitas Gunung Merapi, di utara situs, pada sekitar abad VII-IX $M$ memang sangat intensif dengan seringnya meletus. Puncaknya adalah letusan yang terjadi pada tahun $1006 \mathrm{M}$ yang dianggap sebagai bencana yang besar. Intensitas aktivitas Gunung Merapi antara lain menyebabkan pendangkalan sungai di sekitarnya, dan pada gilirannya menyebabkan banjir pada waktu musim hujan. Faktor alam inilah sebagai salah satu faktor paling menonjol dalam runtuhnya Candi Kedulan

\section{KONSEP "RENCANA PELESTARIAN SITUS KEDULAN"}

Konsep "Rencana Pelestarian Situs Kedulan" secara sistematika berisi bab-bab sebagai berikut:

- Pendahuluan, yang terdiri atas Dasar, Latar Belakang Permasalahan, Ruang lingkup, serta Maksud dan Tujuan 
Menurut Soekmono (1993/1994:281), pemugaran pada prinsipnya tidak lain adalah sebagai upaya untuk menyelamatkan dan melestarikan apa yang masih tersisa dari suatu bangunan purbakala. Selanjutnya dijelaskan pula bahwa bingkai akademik pemugaran sebenarnya adalah arkeologi itu sendiri sebagai ilmu yang paling tidak meliputi tiga macam kegiatan. Ketiga kegiatan tersebut adalah: 1) melacak jejak-jejak kebudayaan masa lalu, 2) meneliti dan menafsirkan benda purbakala yang berhasil ditemukan, dan akhirnya 3) mengupayakan perlindungan dan penyelamatan serta pelestariannya (Soejono, 1990: 10).

\section{GAMBARAN UMUM SITUS KEDULAN}

Situs Kedulan secara asronomis terletak pada posisi $110^{\circ} 28^{\prime} 05^{\prime \prime}$ BT dan $7^{0} 44^{\text {' }}$ 28 " LS dan berada pada ketnggian 168,45 m dpl. Secara administratif, Candi Kedulan terletak di Dusun Kedulan, Kelurahan Tirtomartani, Kecamatan Kalasan, Kabupaten Sleman, Provinsi DIY. Lingkungan situs berupa ladang yang ditambang pasirnya oleh penduduk setempat. Di sebelah barat mengalir Sungai Wareng (lebar sekitar 2 meter) dengan debit yang relatif kecil sepanjang tahun.

Situs ini pertama kali ditemukan pada tanggal 24 September tahun 1993 secara tidak sengaja oleh penduduk yang sedang menambang pasir. Sejak itu berbagai kegiatan arkeologis telah dilakukan oleh institusi terkait. Hasil dari kegiatan tersebut adalah berupa rekonstruksi lengkap di atas kertas dan rekonstruksi percobaan, khususnya bangunan utama. Berdasarkan hal itu, maka untuk sementara dapat disimpulkan hal-hal sebagai

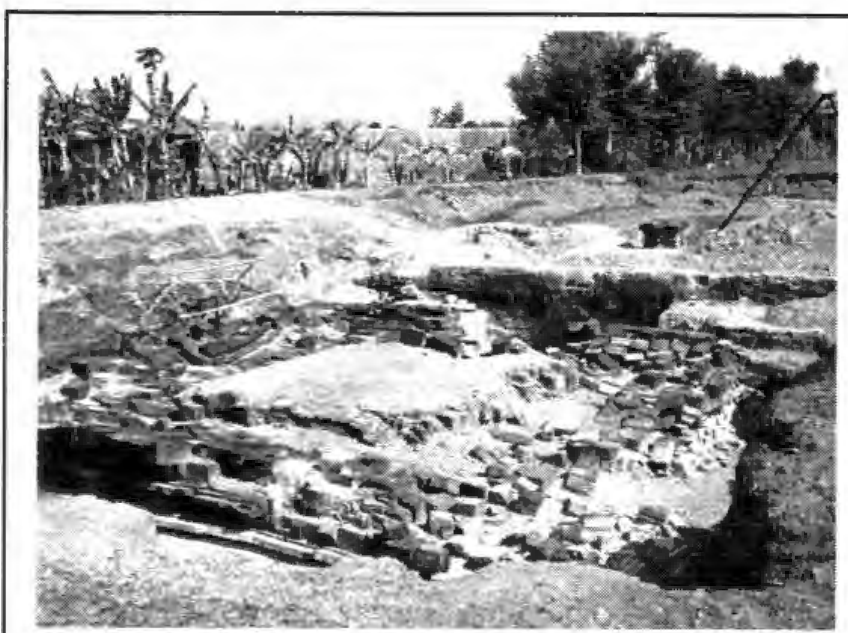

Fondasi bangunan induk Candi Kedulan, ditemukan oleh penambang pasir pada tahun 1993 dan kini siap untuk dipugar berikut:

- bangunan candi menghadap ke timur

- merupakan candi untuk agama Hindu berdasarkan berapa temuan berupa lingga dan yoni, beberapa arca seperti Durga, Ganesa, Mahakala, serta Nandiswara.

- berdenah bujur sangkar dengan ukuran $13,70 \times 13,70 \mathrm{~m}$ 
- Deskripsi Bangunan yang meliputi Data Arsitekural, Data Struktural, Data Keterawatan, dan Data Lingkungan

- Rencana Pelestarian yang terdiri atas Pembebasan Tanah, Pemugaran, Penanggulangan Genangan Air, dan Penataan Lingkungan

- Biaya dan Penutup

Berdasarkan konsep tersebut, ada beberapa catatan yang barangkali dapat dijadikan pijakan dalam membuat gagasan untuk disumbangkan, yaitu:

Secara umum dalam konsep tersebut telah tersirat adanya penekanan pada kerangka pedoman prinsip-prinsip pemugaran seperti tertulis pada halaman 10 . Akan tetapi hal ini belum menjadi "jiwa" dari konsep tersebut karena belum menggambarkan secara menyeluruh dan integral sebagai sebuah kerangka. Salah satu prinsip dasar dalam pemugaran yang menjadi "jiwa" adalah bahwa memugar tidak boleh diartikan sebagai membangun, sehingga rancangannya tidak didasarkan pada imajinasi pemugar tetapi didasarkan pada materi yang tersisa, data yang dijumpai, hasil penelitian dan pendokumentasian, analogi, dsb.

Selain berpedoman pada prinsip-prinsip pemugaran, dalam konsep tersebut juga belum tergambarkan secara spesifik tentang seluk-beluk konservasi (pemugaran) bangunan candi. Seperti diketahui bahwa peninggalan purbakala yang monumental terdiri atas banyak jenis, dan salah satunya adalah candi. Oleh karena itu, gambaran mengenai acuan makna esensi bangunan candi perlu dikemukakan, sekaligus sebagai pendukung dalam proses pemugarannya. Proses dan rancangan pemugaran bangunan candi memiliki kekhususan tersendiri dibandingkan dengan pemugaran mesjid atau monumen yang lain.

Meskipun induk kegiatan dalam konsep ini adalah pelestarian, namun penekanan pada signifikansinya pada pemanfaatan belum tergambarkan. Dalam batas tertentu, orientasi pelestarian yang berorientasi pada pemanfaatan adalah penting sebagai salah satu landasan dalam pelaksanaannya. Dewasa ini, kedua konsep ini terus dikembangkan oleh banyak ahli, khususnya dalam kerangka cultural resource management.

Salah satu hal lagi yang mungkin sangat penting tetapi belum tergambarkan secara jelas adalah usaha untuk membangun jaringan kerja sama dengan berbagai pihak, khususnya dalam kerangka pelestarian. Harus disadari bahwa dewasa ini data arkeologi, benda cagar budaya, warisan budaya, atau apapun namanya, bukan lagi urusan yang dimonopoli oleh kalangan arkeolog. Pandangan yang berkaitan dengan hal itu adalah bahwa warisan budaya (termasuk tinggalan materi) adalah milik semua; bukan hanya pemerintah yang berkepentingan dengan tinggalan itu, tetapi banyak pihak yang juga dapat menghargai dan memanfaatkannya (Layton, 1989; Tanudirjo, 2003: xvii). 


\section{SUMBANGAN PEMIKIRAN}

Berdasarkan uraian di atas, maka beberapa gagasan dan pandangan terhadap konsep sebagai sumbangan atas Rencana Pelestarian Situs Kedulan yang disusun oleh Suaka Peninggalan Sejarah dan Purbakala (sekarang BP3) antara lain meliputi hal-hal sebagai berikut.

\section{5.a Mempertahankan Acuan pada Kerangka Prinsip Pemugaran}

Meskipun tidak tersurat secara detil, namun secara mendasar konsep ini dengan tegas menyebutkan bahwa "...pemugaran sebagai bagian dari upaya pelestarian ... berpedoman pada prinsip-prinsip pemugaran ...". Langkah ini jelas merupakan hal yang menjadi "jiwa" bagi pelaksanaan pelestarian. Namun demikian, kerangka prinsip pemugaran khusus bangunan candi semestinya mendapat porsi yang khusus, karena obyek yang digarap adalah candi. Dengan demikian, maka untuk mengimplementasikan konsep pada tataran operasional akan lebih sistematis dan tentu saja diharapkan dapat berjalan dengan baik.

5.b Mengacu pada Makna Esensi Bangunan Candi: Obyek pelestarian dalam konsep ini adalah bangunan candi, sehingga dalam pelaksanaan pemugarannya sangat penting artinya untuk mengacu pada makna esensi bangunan candi. Beberapa hal berkaitan dengan hal ini antara lain dapat disimak dalam Anom (1997), khususnya untuk candi-candi di Jawa Tengah dan DIY, seperti butir-butir berikut ini.

- Bangunan candi dapat dikaji menurut aspek teknis maupun aspek keagamaan. Yang dimaksudkan dengan aspek teknis adalah segala sesuatu yang berkaitan dengan masalah perencanaan atau pendirian candi, baik teknik konstruksi seperti bahan bangunan, cara pembuatan, maupun aspek arsitektural yang berkaitan dengan segi keindahan. Sedangkan aspek keagamaan meliputi segala sesuatu yang berhubungan dengan masalah keagamaan selain ajaran agamanya, seperti upacara dan simbol-simbol (13-14)

- Candi merupakan tempat tinggal para dewa, maka lokasi tempat candi itu berdiri pun harus mencerminkan istana para dewa di kahyangan yang serba indah dengan taman penuh bunga dikelilingi kolam atau danau (105)

- Berdasarkan bentuk dan fungsinya, candi juga dapat disebut sebagai:

- Devagriham / devalaya: tempat tinggal para dewa

- Kailāsa: tempat duduk Siwa di Gunung Himalaya

- Mandeva: tangkai pengaduk susu yang berada di atas kura-kura

- Gunung Meru: gunung dengan beberapa puncaknya

- Präsäda: tempat duduk dewa

- Vimāna: aspek teknis dan agama, yaitu bahwa candi diciptakan berdasarkan tradisi (śāstra) dengan penetapan berbagai ukuran standar dan proporsional. Dalam hal ini ukuran dan proporsi sangat penting 
sehingga kesalahan dalam penggunaan ukuran dapat berakibat fatal, yaitu candi bukan menjadi tempat tinggal dewa melainkan tempat setan (bhuta) (290-291)

- Perancangan bangunan serta tata letak candi Hindu atau pun Buddha, khususnya di Jawa Tengah dan DIY, dibuat berdasarkan diagram yang sama, yaitu vāstupuruşamañdala (390)

- Bagian-bagian bangunan candi meliputi:

- Kaki candi terdiri atas pāda dan pañcakarma yang melambangkan pañcamahäbütha, lima elemen pembentuk dunia

- Pradaksinapatha: (jalan keliling) yang dibuat dengan memperlebar kaki candi ke segala arah sehingga dapat dipakai sebagai jalan mengelilingi tubuh candi untuk selanjutnya menuju bilik utama. Perjalanan ini diasosiasikan dengan seluruh perjalanan hidup manusia hingga bersatu dengan maha pencipta

- Bilik candi: simbol gua yang biasa disebut dengan garbhagrha, tempat tersimpannya benih candi, atau tempat didirikannya arca utama candi itu

- Atap candi: sering mendominasi keseluruhan bentuk candi. Atap yang tinggi, runcing, bertingkat, adalah simbol puncak Gunung Meru, tempat para dewa (404-407)

- Secara umum, candi-candi di Jawa Tengah dan DIY memiliki keterpaduan antara aspek teknis dan keagamaan, serta bagian-bagiannya memiliki persamaan dengan bagian-bagian tubuh manusia

5.c Berorientasi pada Pemanfaatan: Antara pelestarian dan pemanfaatan sebenarnya memiliki hubungan yang resiprokal, artinya pelestarian akan signifikan jika dimanfaatkan dan pemanfaatan dapat digunakan untuk mendukung pelestarian. Berkaitan dengan pemanfaatan, Cleere (1989:10) mengemukakan tentang tumpuan pemanfaatan heritage yang mencakup manfaat ideologik (edukasional), akademik (ilmu pengetahuan), dan ekonomik (pariwisata). Sedangkan Haryati Soebadio (1993/1994: 4-9) secara khusus menyoroti pemanfaatan peninggalan sejarah yang dibaginya menjadi dua, yaitu pemanfaatan fisik (pariwisata) dan pemanfaatan non-fisik (berkaitan dengan makna kultural dan nilai luhur) yang keduanya dapat berjalan bersama. Dengan demikian menjadi penting artinya untuk menekankan orientasi rencana pelestarian pada aspek pemanfaatan. Khusus untuk pemanfaatan secara ekonomik, selain dapat menjadi pendorong juga perlu diperhatikan aspek potensi kerusakannya seperti dikhawatirkan Renfrew dan Paul Bahn (1996: 521) bahwa pariwisata merupakan potensi perusak situs yang tidak disadari.

\section{5.d Membuka Diri untuk Menjalin Kerja Sama}

Seperti dikemukakan oleh Cleere bahwa pemanfaatan heritage meliputi pemanfaatan ideologik, akademik, dan ekonomik. Sementara itu, pemanfaatan 
menjadi tidak ada artinya jika aspek pelestarian tidak diperhatikan. Berdasarkan hal ini, maka dalam "Rencana Pelestarian Situs Kedulan" secara dini perlu membuka diri untuk bekerja sama, baik dalam tataran pelestarian maupun pemanfaatan; baik dalam tahap perencanaan maupun pelaksanaannya. Beberapa pihak yang perlu dijajaki untuk secara bersama-sama mengembangkan situs Kedulan, yang secara teknis sudah "siap pugar" ini, antara lain kalangan akademik baik institusi penelitian maupun perguruan tinggi; institusi birokrasi (Pemda); institusi pengembang kepariwisataan; serta kalangan lainnya yang memiliki integritas pada pengembangan situs ini. Dengan kerja sama yang luas dan intensif, maka usaha pelestarian dan pemanfaatan Situs Kedulan dapat berjalan secara seimbang, dan pada akhirnya harapan banyak pihak untuk "memanggungkan kembali" Candi Kedulan dapat segera menjadi kenyataan.

\section{PENUTUP}

Latar belakang untuk memberikan sumbangan pemikiran bagi konsep "Rencana Pelestarian Situs Kedulan" antara lain didasarkan pada kenyataan bahwa situs ini bukan hanya penting bagi arkeolog atau kalangan akademik lainnya, akan tetapi dalam batas tertentu juga memiliki arti penting bagi kalangan lainnya baik pemerintah, masyarakat setempat, maupun masyarakat dalam arti yang luas. Secara teknis Candi (induk) Kedulan memang sudah dalam tahap "siap pugar" setelah sejak 1993 secara intensif diteliti dan dilakukan upaya rekonstruksi. Oleh karena itu usulan untuk melestarikan situs ini melalui sebuah konsep perlu didukung oleh banyak pihak.

Beberapa sumbangan pemikiran yang dapat disampaikan dalam kesempatan ini adalah bahwa dalam perencanaan dan pelaksanaannya, konsep pelestarian yang diusulkan perlu dikembangkan untuk:

- Mempertahankan acuan pada kerangka prinsip pemugaran

- Mengacu pada makna esensi bangunan candi

- Berorientasi pada pemanfaatan

- Membuka diri untuk menjalin kerja sama 


\section{DAFTAR PUSTAKA}

Anom, I.G.N. 1997. Keterpaduan Aspek Teknis dan Aspek Keagamaan dalam Pendirian Candi Periode Jawa Tengah (Studi Kasus Candi Utama Sewu). Disertasi. Universitas Gadjah Mada, Yogyakarta.

Atmadi, Parmono. 1981. "Beberapa Masalah dan Aspek Utama dalam Kegiatan Pemugaran Bangunan Sejarah dan Purbakala". Majalah Arkeologi. Tahun IV, No. 1-2, 1982: 42-53.

Bambang PH \& Tri Hartono. 1997. "Perlindungan dan Pemeliharaan Benda Cagar Budaya". Cinandi. Panitia Lustrum VII Jurusan Arkeologi Fakultas Sastra, Universitas Gadjah Mada.

Basoeki. 1982. "Beberapa Aspek tentang Rekonstruksi Bangunan-bangunan Purbakala di Indonesia". Proceedings Pertemuan Ilmiah Arkeologi (PIA) II di Jakarta, Februari 1980. Puslit Arkenas, Jakarta. Hlm. 623-633.

Layton, R. 1989. "Introduction: who needs the past". Dalam R. Layton (ed.). Who Needs the Past?. Unwin Hyman, London.

Nugroho, Suwarso Alip. 2000. Pengaruh Letusan Gunung Merapi terhadap Candi Sambisari, Candi Kedulan, dan Candi Morangan. Skripsi. Fakultas Sastra, Universitas Gadjah Mada, Yogyakarta.

Price, Nikolas Stanley P. 1990. "Conservation and Information in the Display of Prehistoric Site". Dalam P. Gathercole and D. Lowenthal (eds.). The Politics of the Past. Unwin Hyman, London.

Renfrew, Colin \& Paul Bahn. 1996. Archaeology. Theories, Method, and Practise. $2^{\text {nd }}$ edition. Thames and Hudson Ltd, London.

Schiffer, Michael B.\& George J. Gumerman (ed.). 1977. Conservation Archaeology. A Guide for Cultural Resources Management. Academic Press, Inc, New York.

Soebadio, Haryati. 1993/1994. "Arkeologi dan Pengembangan Sosial-Budaya Bangsa". Dalam Proceedings Pertemuan Ilmiah Arkeologi VI. Pusat Penelitian Arkeologi Nasional, Jakarta. Hlm. 3-13. 
Soediman. 1982. "Catatan tentang Berbagai Masalah dalam Pemugaran Candi". Proceedings Pertemuan Ilmiah Arkeologi (PIA) II di Jakarta, Februari 1980. Pusat Penelitian Arkeologi Nasional, Jakarta. Hlm. 635-657.

Soejono, R. P.1990 ."Eminence and Projection of Archaeological Research in Indonesia". Saraswati: Esai-esai Arkeologi. Pusat Penelitian Arkeologi Nasional, Jakarta. Hlm. 9-21.

Soekmono, R. 1993 / 1994. "Pemugaran dan Arkeologi". Proceedings Pertemuan Ilmiah Arkeologi VI di Batu, Malang, Jawa Timur. Juli 1992. Pusat penelitian Arkeologi Nasional. Hlm. 279-285.

Suaka Peninggalan Sejarah dan Purbakala. 2000. Rencana Pelestarian Situs Kedulan. Tidak diterbitkan.

Subroto, Ph. 1997. "Kondisi Situs Trowulan dan Usaha-usaha Pelestariannya". Makalah disampaikan dalam acara Saresehan mengenai BCB di Pacet, Jawa Timur, 25-26 Februari 1997.

2003. "Pemanfaatan Benda Cagar Budaya Bangunan Bata Pasca Pugar untuk Kepentingan Pendidikan dan Ilmu Pengetahuan". Makalah disampaikan dalam Rapat Penyusunan Kebijakan Pemanfaatan BCB di Cisarua, Mei 2003.

Tanudirjo, Daud Aris. 1998. "Cultural Resource Management sebagai Manajemen Konflik”. Artefak. No 19/Februari 1998. Hlm. 14-18.

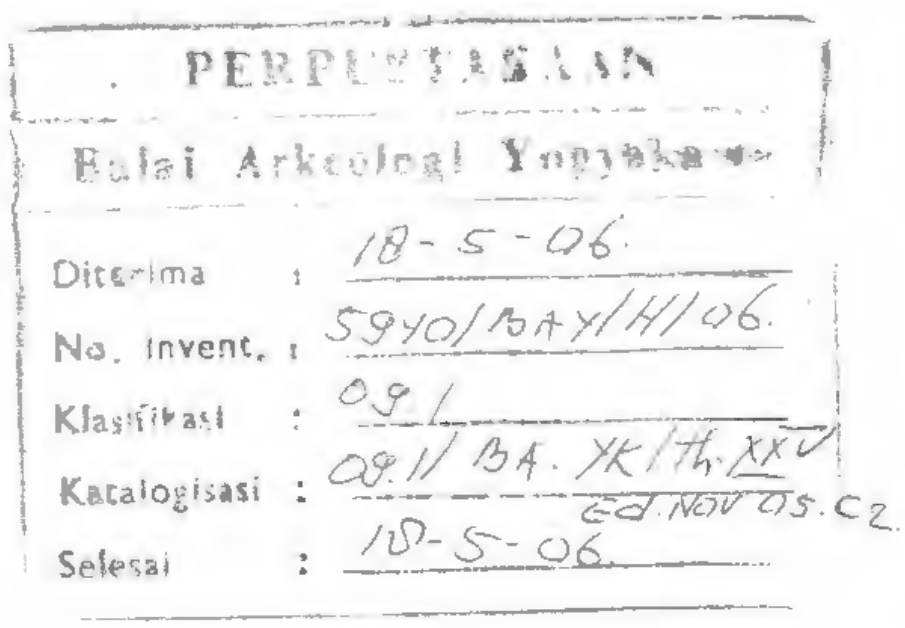

